\title{
E-Satisfaction as A Reflection of E-Marketing and E-Sequal in Influencing E-Loyalty on E-Commerce
}

\author{
Peri A. Manaf ${ }^{1 *}$, Ivany Rachmawati ${ }^{2}$, Marcella Witanto ${ }^{2}$, Adityo Nugroho ${ }^{2}$ \\ ${ }^{1}$ Bina Nusantara University, Jakarta, Indonesia \\ ${ }^{2}$ Bina Nusantara University, Tangerang, Indonesia \\ *Corresponding author E-mail: Pmanaf@binus.edu
}

\begin{abstract}
Online shopping is becoming a trend in Indonesia. Seeing the trend many new e-commerce began to emerge. And the consumer will try to find out which marketplace can meet their expectations. The purpose of this study is to propose an integrative model of the e-loyalty development process and to test the model empirically and see how big the influence between e-marketing and e-service quality toward e-loyalty mediated by e-satisfaction. For this purpose, data was collected from a sample of 100 consumers in Java Island ie Banten, DKI Jakarta, DI Yogyakarta, West Java, Central Java, and East Java. The selection of samples was done by purposive sampling. The data used in this study is the primary data. SmartPLS has been used for data analysis. Data was analyzed to obtain hypothesis test. The study showed e-loyalty customers at E-Commerce's website in Indonesia are influenced by e-satisfaction, where e-satisfaction is influenced by e-sequal and e-marketing. Moreover, the result also showed e-sequal affects e-loyalty more strongly than e-marketing with e-satisfaction as mediator.
\end{abstract}

Keywords: Online Shoppers, E-Sequal, E-Marketing, E-Satisfaction, E-Loyalty, Website, E-Commerce

\section{Introduction}

The development of Internet-based information technology is very popular in Indonesia. Based on the report of Indonesian Internet Service Provider Association (APJII), more than 50 percent or about 143 million people have been connected internet network throughout 2017. So, Indonesia still has great potential to enlarge its internet users in the near future. Utilization of the existence of the internet itself has grown further, not only to communicate but also to buy goods, order transportation, to do business and work. Online shopping becomes internet activity which is quite popular in Indonesia. Ease of transactions, the speed of the shopping process become consideration why online shopping activities selected by consumers. This phenomenon changed the consumer behavior on spending patterns. Online shopping trends are increasing and consumers more intent spending money on needs lead to pleasure. Increased public interest in online shopping can be seen from the value of transactions listed on the National Online Shopping Day (Harbolnas) 2017 which reached Rp 4, 7 trillion. The number is significantly increased compared to similar events last year which recorded transactions Rp3, 3 trillion.

The fact that shows the increasing value of online shopping transactions become a proof that internet-based buying and selling system is increasingly in demand by the public and prove that shopping over the internet is now very trustworthy for customers. Customer Behavioral patterns shift from online stores to offline stores, as reported in the ShopbackInsight, which says that the increase has continued since 2015 by $11 \%$ until 2017 reached $41 \%$ of the total population of Indonesia. This makes company should pay more attention to the opportunities available in the internet. The growth of sales figures in e-commerce industry from year to year lure other retail business to choose other distribution channels. Demonstrated by survey of Consumer Insight Nielsen Indonesia, in 2017, Harbolnas participants increased by 254 ecommerce, compared to 2011 as much as 211 ecommerce. As a result, competition is rising sharply among e-commerce. This growing number of e-commerce has led many companies to struggle for top positions by performing various online marketing strategies.

Conformed to the competition in today e-commerce there have been many strategies for e-commerce platform to plan and implement. Day by day competition have been increase, it is proven by shifting customer behavior post digital technology era. In this day, with the increasing recognition of the important of customer satisfaction and loyalty, company now understand the importance of services and marketing strategy. So the problem faced by e-commerce today is how to create loyal customers. Loyalty can be created because of existence satisfaction on customer. It is important for companies to pay attention to other things besides adjust to customer needs and desires, that is how to create comfort for customers to build satisfaction. E-commerce needs to provide good service and create an attractive marketing strategy to maintain sustainable satisfaction to create engagement with customers.

This study discuss about the issue that exist in the previous literature, that state about how e-sequal and e-marketing influencing e-satisfaction and also how e-satisfaction influencing e-loyalty. In previous research e-sequals showed a positive influence on e-satisfaction, either directly or indirectly [1] and also e-marketing activities can affect customer satisfaction [2]. Ref. [3] was found that customer e-loyalty was influenced by customer esatisfaction, and e-satisfaction of customers directly impacted [4] and positive [1] on customer e-loyalty. there are other studies that 
showed inconsistent finding. Ref. [5] suggests that e-sequal negatively affects e-satisfaction. In contrast to other research results state that digital marketing does not affect e-satisfaction [6]. Ref. [7] also reveal that customer satisfaction does not affect loyalty and not mutually representative [8]. This study recognizes the void present in the literature and argues that the development of e-loyalty can be well described in a comprehensive e-marketing and e-sequential framework for e-loyalty that can also be mediated by e-satisfaction. However, in previous study, there are inconsistency finding made by the research. Therefore, from this model, researcher want to replicate to know which theory that suitable with Indonesian e-commerce condition. However, in previous studies, no e-marketing variables and e-service quality tests have been conducted against e-loyalty mediated by $\mathrm{e}$ satisfaction in one model. So this study is a study that uses a new model that has never been used before. The purpose of this study is to propose an integrative model of the e-loyalty development process and to test the model empirically and see how big the influence between e-marketing and e-service quality toward eloyalty mediated by e-satisfaction. The following questions guide research:

1. Does e-sequal have a significantly positive influence on esatisfaction?

2. Does e-marketing have a significantly positive influence on esatisfaction?

3. Does e-satisfaction have a significantly positive influence on e-loyalty?

\subsection{Significance of this study}

In a theoretical point of view, this study provides empirical testing of a comprehensive model to examine variables that might have an effect on online customer loyalty. This is expected to enrich the discussion of online customer loyalty by proposing other variables. This study contributes to the development of e-loyalty by incorporating critical construction into the framework. First, the current study seeks to build a comprehensive framework of eloyalty development process by examining the simultaneous impact of e-marketing and e-sequences on e-loyalty. Secondly, it seeks to build a comprehensive framework of e-satisfaction development process by examining the simultaneous impact of emarketing and e-sequences on e-loyalty. And another important aspect that can be explained from this study is whether the construct of e-satisfaction will mediate between e-marketing and e-sequal against e-loyalty.

On the other hand, from a practical perspective, this research is important to provide strategic direction of e-commerce in their efforts to compete to become a market leader in the e-commerce sector. What are the top priorities as a business tool for improving e-loyalty. In addition, the existence of e-satisfaction as a mediating variable provides a more understanding of as a useful input for reinforcement in market segmentation.

\section{Literature review}

The Internet is changing people's habits, one of which is meeting their needs [1], they switch online purchases due to technological developments, where purchases can be made anytime in a virtual and global manner [9] that supported by the increasing use of smartphones, foreign investment, the growth of the middle class, as well as easier way of payment, which then created business competition in the form of retailing platform [4]. Companies are starting to use e-commerce as a channel to marketing their products [2]. E-commerce makes transaction activity faster, flexible and cost-effective in entering the market not only locally but also internationally.

In 2017 more than 50 percent of Indonesia's population is already connected internet network according to APJII report. Markplus
Insight and Online Marketer Magazine research results say that people's interest in online shopping will continue to increase about 24.2 million people every year.

\subsection{E-Sequal}

E-sequal is a perception of the service quality over the internet [10] that adapted to consumer assumptions about a service offered [10], The concept of e-sequal is to integrate Internet-based services that connected with company to strengthen customer relationships [3] to support the customer's online shopping activities [5] as effectively and efficiently during shopping and delivering purchased products [3]. Easy and secure payment methods can increase your customers' online shopping interests. The website design is an instrument to provide effective online services and internet marketing to online shoppers [5]. E-sequal helps e-commerce to create appropriate strategies to improve service [10]. by evaluating service and perceive customer [10]. Ref. [3] states that service quality should start from customer needs, then it will impact on customer satisfaction and end on customer loyalty. Therefore, good service quality is expected to improve customer satisfaction and high customer satisfaction can generate customer loyalty.

\subsection{E-Marketing}

Ref. [11] said that e-marketing is known as digital marketing, which is the process of value exchange, both products and services, and also can serve as a medium for maintaining good relationships to create "digital relationships" with customer [12]. So the company is advised to do marketing activities by utilizing internet and technology [11], because it is more innovative in creating good relationship between company and customer [11], it can shorten the time of dissemination of information and dissemination can be wider [11].

There are 13 criteria to evaluate a website, which can be used as a good website indicator. However, there are 4 most appropriate criteria to evaluate e-commerce website: credibility, accessibility, accuracy, and currency. Accessibility indicates the accessibility level of the website, this indicator also applies to users with disabilities [13]. Accuracy indicates how the website can provide factual, reliable and up-to-date [13] information. Credibility indicates the information presented on the website can be distinguished. Currency indicates the timeliness of information delivery in a new way because it is very important for users to obtain the latest information [13].

E-Commerce realizes the importance of marketing activities that are given digitally in order to create and improve customer loyalty, by way of innovation through attractive website appearance. One of the innovations provided by E-Commerce is a selection certain product categories, making it easier and faster for customer to find goods in those categories. E-Commerce also offering certain promos that placed in the topmost column of website.

\subsection{E-Satisfaction}

The existence of online shopping provides satisfaction for customers while shopping because of the convenience and quickness of the purchasing process offered [14], where customers can shop from wherever they are just by using the internet network. E-Satisfaction is a customer's assessment of a product or service [1] based on buying experience [5] on an e-commerce. Esatisfaction is influenced by website design [3] that can assist customer during conducting online transactions [5].

Customers with high e-satisfaction will provide benefit the ecommerce, such as willing to pay more for products or services, this can be a competitive advantage in competition and become 
one of the factors for e-commerce success [1], because it can create long-term relationships with customers [5] and create profit [5] of repeat purchases [3]. Dissatisfied consumers will switch to competitors [5]. Customer dissatisfaction on an e-commerce causes website visitors to decline.

\subsection{E-Loyalty}

E-loyalty is a form of customer willingness for ongoing visits websites virtually [3] that will creating brand recognition to consumers [11] by combine customer spending and attitude behavior [3] to commit repeat purchases on the website [3] and do not move to other e-commerces [3]. E-loyalty consumer is crucial for the sustainability of an e-commerce, as the costs of acquiring new customers are more expensive than maintaining of existing customers. Ref. [1] says that the higher e-loyalty can create efficiency for the company. To address the issue of the competitive environment and to support e-commerce success, companies need to create loyal customers [1] which then result in repetitive purchasing behavior [5].

E-Commerce also trying to create loyal customer using promo like "Flash Sale" at the appointed time to making online purchases repeatedly on E-Commerce website. E-Commerce offers a wide range of items with great discounts, so it can attract customers' desire to buy at the promo.

\subsection{E-Sequal, E- Marketing, E-Satisfaction and E- Loyalty}

E-Sequal has a powerful impact [1] and can be a predictor for the assessment of customer satisfaction quality [15], because the shopping experience can create e-satisfaction of online shoppers [1][5]. E-sequal can create a company's differences with other companies so as to increase customer satisfaction that impacts repeat purchases as a form of customer loyalty [1]. In previous research e-sequals showed a positive influence on e-satisfaction, either directly or indirectly [1]. However, there are other studies that suggest that e-sequal negatively affects e-satisfaction [5]. Hence the hypothesis proposed in this research is e-sequal have a significantly positive influence on e-satisfaction.

H1: E-sequal have a significantly positive influence on esatisfaction

The basis of the company's marketing activities is to generate customer satisfaction and loyalty [16] to get new customers and retain existing customers [2] by maintaining good relationships with these customers. To maintain customer relationship, company needs to create and improve customer satisfaction [4] by proper marketing activities [2]. In a previous study it was said that e-marketing activities can affect customer satisfaction [2]. In contrast to other research results state that digital marketing does not affect e-satisfaction [6] which is also supported by other research.

$\mathrm{H}$ 2: E-marketing have a significantly positive influence on esatisfaction

The relationship between customer satisfaction and customer loyalty applies not only to offline stores, but also to online. Customer e-satisfaction is one of the most important things in competition, because an increase in e-satisfaction will increase customer loyalty $[1,3]$. In other words, satisfied customers can be one of the loyal customer characteristics [17]. In a previous study it was found that customer e-loyalty was influenced by customer e-satisfaction [3], and e-satisfaction of customers directly impacted [4] and positive [1] on customer e-loyalty. However, some studies also reveal that customer satisfaction does not affect loyalty [7]. But in another study it was said that customer satisfaction and loyalty are not mutually representative [8]. So in this study found the hypothesis that e-satisfaction have a significantly positive influence on e-loyalty.
H3: E-satisfaction have a significantly positive influence on eloyalty

\section{E-Sequal}

\section{IVIethods}

\subsection{Research design}

This type of research uses descriptive-explanatory design, where descriptive which includes data collection for hypothesis tested or answering questions about the last status of research subjects [18] and explanative ie the use of available data to explain the causal relationship between variables through hypothesis testing. While the unit of analysis is an individual ie everyone who has ever visit E-Commerce's Website.

\subsection{Sampling}

The population in this study is a visitor E-Commerce's website in Indonesia. The sample to be used is a small population-based sample. Based on a survey conducted by APJII, which states that the penetration of internet users in Indonesia by $54.04 \%$ is in Java, the researchers decided to focus on the research sample used by visitors of E-Commerce's website in Java Island ie Banten, DKI Jakarta, DI Yogyakarta, West Java, Central Java, and East Java. Sampling technique using Purposive Sampling Method. Because researchers determine the characteristics of the sample of consumers who have visited the E-Commerce's website. The number of samples obtained by calculating number of $\mathrm{E}$ Commerce's website visitor with Voorhis and Morgan formula (N $=50+8(\mathrm{~m}))$ is as much as at least 66 respondents. Although the number is sufficient to represent the population, the researcher decided to get 100 respondents for the sample.

\subsection{Data and data collection methods}

The type of data used in this study is the primary data by distributing the questionnaires with likert scale from one (1) Strongly Disagree to five (5) Strongly Agree. Questionnaires writing is prepared using an instrument of questions to determine the effect of some related variables.

\subsection{Analysis tool}

Data analysis used by researcher in this research is quantitative analysis. The hypothesis design will be analyzed using SmartPLS 2.0 software to test the relationship between variables. Jogianto (2009: 11) states PLS is a multivariate statistical technique that performs benchmarking on each variable.

\subsection{Measurement model}

Test convergent validity and composite reliability or cronbach is the right model to do reflective testing. Cronbach alpha is discussing how a question becomes a variable indicator to display convergent validity and display reliability, which if the number produced is greater than 0.70 then a scale is acceptable [19]. AVE can display a similarity of averages to show the latent factor in the reflective model, is used to test convergent and divergent validity [20][21], which the value must have a scale greater than 0.5 , because if AVE is below 0.5 then the scale has an error variance. The set of questionnaires already through validity and reliability test. The test result shows that the measurement model is validated 
because the overall of AVE is greater than 0.5. And also the data are reliable because the value of Cronbach's alpha was obtained above 0.70 . Multicollinearity Test is done to find out that there is correlation between independent variables in regression model, According to [22] cutoff value that showing the existence of multicorrelation is VIF Value less than 3.3. The test result shows that all independent variables (E-Marketing and E-Sequal) are not correlating to each other since VIF < 3.3 with each VIF value was below 3.3. Then the research data worth to used. Heteroscedasticity test is done to find out that examination dissimilarity residual one observation to other observation in regression model used. The test result shows there is no heteroscedasticity, Then the research data worth to used.

\subsection{Hypothesis testing research}

The test is done by comparing P-Value with 0.05 , the result shows independent variable influence dependent variable when P-Value $<0.05$. The test is to observe independent variable influence dependent variable directly (without mediator).

H1 claim that e-sequal have a significantly positive influence on esatisfaction. The test result is P-Value of 0 , since p-value is lower than 0.05 , which predicted $\mathrm{H} 1$ accepted. It was support by accomplish research by [1] that state e-sequal have a significan positive effect on e-satisfaction. $\mathrm{H} 2$ claim that e-marketing have a significantly positive influence on e-satisfaction. The test result is $\mathrm{P}$-Value of 0.014 , since p-value is lower than 0.05, which predicted $\mathrm{H} 2$ accepted. It was support by accomplish research by [23] that state e-marketing can affect positively on e-satisfaction. $\mathrm{H} 3$ claim that e-satisfaction have a significantly positive influence on e-loyalty. The test result is P-Value of 0 , since p-value is lower than 0.05 , which predicted $\mathrm{H} 3$ accepted. It was support by accomplish research by [3] that state e-satisfaction affects eloyalty significantly. The hypothesis test results founds that emarketing (0.276) is stronger affecting e-loyalty directly than esequal (0.082). The result also show that e-sequal does not affect loyalty directly, because p-value (0.612) was obtained greater than 0.05 . It shows that e-satisfaction is needed for mediator role.

\section{Discussion}

The purpose of this research is to propose an integrative model of the e-loyalty development process and to test the model empirically and to see how big the influence between e-marketing and e-service quality toward e-loyalty mediated by e-satisfaction. For this purpose, data was collected from a sample of 100 consumers in Java Island ie Banten, DKI Jakarta, DI Yogyakarta, West Java, Central Java, and East Java. The hypothesis analysis shows that e-sequal have a significantly positive influence on esatisfaction. By the test result, e-sequal needs e-satisfaction for mediating influence on e-loyalty. This is appropriate to [3] the higher service quality will create higher customer satisfaction of that e-commerce. Service quality can be showed by simplicity and security of payment process, and also more variance of trustworthy shipment partner. Some e-commerce added "Live Chat" feature which is communication media between customer and seller, it is facilitate customer to get clarity information about the product to be purchased. Furthermore, a quality and design of website also determining customer e-satisfaction during online shopping. However, the quality of an e-commerce service also comes from the services provided by sellers who join in the ecommerce. Then e-commerce has to be more selective on seller, because seller is one of the representative of e-commerce.

The hypothesis analysis shows that e-marketing have a significantly positive influence on e-satisfaction. This is appropriate to [16] which says that essential of marketing activities is create customer satisfaction and loyalty. Digital relation is required between customer and company for e- commerce. Accuracy information about product can be customer consideration in making purchase decisions and repurchase through e-commerce. Moreover, easiness in getting needed information can increase customer satisfaction. As for efforts to create convenience given, E-Commerce added search bar, filter for product category, and information about promotion that set in first interface. The displayed information through the website should be maintained periodically to keep the information up-to-date. However, maintaining should have a consistent time, so users are not disappointed because of the decline in website performance due to maintenance.

The hypothesis analysis shows that e-satisfaction have a significantly positive influence on e-loyalty. When customer is satisfied, customer have intention to make repeat purchases on the e-commerce and become a loyal customer. This is appropriate to [17] research which say that satisfied customers can serve as one of the loyal customer. Then the results showed that e-sequal is a stronger independent variable in affecting e-loyalty with esatisfaction as a mediator. So when e-commerce wants to create loyal customers, improving service quality to match or exceed customer expectations becomes an important focus in their strategy.

\subsection{Managerial implication}

E-commerce needs to pay attention to the importance of loyal customers, namely by increasing customer satisfaction through services and marketing strategies. Basically e-marketing can help companies reach wider targets than conventional marketing. Therefore, this can help increase company sales. SEO optimization needs to be done to make the website easily recognizeable. And with the advancement of technology and the existence of social media, it is easier for companies to communicate with consumers. Therefore, the easier it is to build relationships with consumers and opens up opportunities increase consumer loyalty.

On the other hand, the use of e-marketing as a messenger of information must be clear, consistent and informative. Such as information about how to use the website, applicable provisions, and ongoing promotions. The practicality of shopping through ecommerce can increase the buyer's negligence, so often buyers get a negative impact after purchase. Therefore, e-commerce needs to put important information on the visible spot with grammar that is easy to understand, concise, and clear, as well as the color and size of the letters that convenient to see (colors that are not too bright and the size of the writing not too small).

The service quality is also important because it will have a direct impact on the customer's satisfaction. Good service quality will be an advantage for the company to provide good feedback, and it is not impossible to become a repeat buyer. Therefore, it is very important to consider aspects of customer satisfaction related to the quality of services provided, such as the form of convenience, speed, ability, and hospitality. The appearance of the website is sometimes discomfort for users. The availability of online customer services will greatly help users in facing difficulties in use. Adding recognized vector icons makes the user easier and faster in finding the category needed.

E-Commerce makes sellers become partners as a product provider to meet the needs and want of their customers. Selling online makes customers unable to see and feel the direct product they want to buy. Sometimes misused by the seller to sell products that are not consistence with the description and appearance of the product on the platform, delayed delivery process, delivery of damaged/inappropriate products and not compatible to that specifications, and delivery of products less than the amount should be shipped. It can impact on reducing customer satisfaction, the customer's desire to repurchase, and raise up bad information in word of mouth. To deal with this, e-commerce 
must make strict and binding regulations for sellers, as well as penalties that make the culprit deterrent.

\section{Conclusion}

The results of this study show that E-loyalty of customers at ECommerce's website in Indonesia are influenced by e-satisfaction, where e-satisfaction is influenced by e-sequal and e-marketing. Emarketing affects e-loyalty more strongly than e-sequal. Therefore, when e-commerce company want to create loyal customers, the accuracy information about product becomes an important focus in their strategy to create digital relation between customer and company. Easiness in getting needed information also determining customer e-satisfaction during online shopping with quality and design of website. Website needs to make sure the information up-to-date and website is going well, so maintain periodically in consistent time is needed. E-commerce company have to be more selective on seller as a representative of company to serve customers well and appropriately.

\section{Acknowledgments}

We would also like to show our gratitude to Dr. Peri A. Manaf, Lecturer of Magister Manajemen at BINUS University for sharing his pearls of wisdom with us during the course of this research.

\section{References}

[1] Sharma G. "Service Quality, Satisfaction and Loyalty on Online Marketing: An Empirical Investigation", Global Journal of Management and Business Research: E Marketing, Vol. 17, Issue 2, (2017).

[2] Anda, Karkar, \& Akbiyik, "Customer Satisfaction Factor in Digital Content Marketing: Isparta Province as an Example", Internationa Journal of Social Science Studies, Vol. 4, No. 5, (2016).

[3] Romadhoni, Buyung, Hadiwidjojo D, Noermijati, \& Aisjah S, "Relationship between E-Service Quality, E-Satisfaction, E-Trust, E-Commitment in Building Customer E-Loyalty: A Literature Review", International Journal of Business and Management Invention, Vol. 4, Issue 2, (2015).

[4] Rajarajan M \& Vetriveera R. "Customer satisfaction toward online marketing - an empirical study", (2016).

[5] Chinomona, Richard, Masinge G, \& Sandada M, "The Influence of E-Service Quality on Customer Perceived Value, Customer Satisfaction and Loyalty in South Africa", Mediterranean Journal of Social Sciences, Vol. 5, No. 9, (2014).

[6] Marliya, Mei N \& Wahyono, "Membangun consumer loyalty melalui social media", Management Analysis Journal, Vol. 5, No. 3, (2016).

[7] Ponirin, Scott DR, von der Heidt T, "Does e-store service quality affect customer loyalty?", Social Science Research Network, (2009).

[8] Shankar V, Smith AK \& Rangaswamy A, "Customer satisfaction and loyalty in online and offline environments", Intern. J. of Research in Marketing, Vol. 20, (2003), pp: 153-175.

[9] Maiyaki AA \& Mokhtar SSM, "Icorrelates of consumer online buying behaviour", International Journal of Management and Applied Science, Vol. 2, Issue 1, (2016). ISSN: 2394-7926.

[10] Al-dweeri RM, Obeidat ZM, Al-dwiry MA, Alshurideh MT \& Alhorani AM, "The Impact of E-Service Quality and E-Loyalty on Online Shopping: Moderating Effect of E-Satisfaction and ETrust", International Journal of Marketing Studies, Vol. 9, No. 2, (2017).

[11] Khan A \& Islam MA, "The Impact of digital marketing on increasing customer loyalty: a study on Dhaka City, Bangladesh", International Journal of Economics, Commerce and Management, Vol. V, Issue 4, (2017).
[12] Kannan PK \& Li A, 2Digital marketing: A framework, review and research agenda", International Journal of Research in Marketing, Vol. 34, (2017), pp: 22-45.

[13] Hassan S, "Evaluation of Saudi Educational Websites", The International Journal of E-Learning and Educational Technologies in the Digital Media (IJEETDM), Vol. 2, No. 4, (2016), pp: 141147.

[14] Falode BO, Amubode AA, Adegunwa MO \& Ogunduyile SR, "Online and Offline Shopping Motivation of Apparel Consumers in Ibadan Metropolis, Nigeria", International Journal of Marketing Studies, Vol. 8, No. 1, (2016).

[15] Wolfinbarger M \& Gilly MC, "eTailQ: dimensionalizing, measuring and predicting retail quality", Journal of Retailing, Vol. 79, (2003), pp: 183-198.

[16] Moriuchi, Emi \& Takahashi I, "Satisfaction trust and loyalty of repeat online consumer within the Japanese online supermarket trade", Australasian Marketing Journal, Vol. 24, (2016), pp: 146156.

[17] Chu SY, Wu CM, Wu KIF \& Chen YF, "Does an Established Offline Store Drive Online Purchase Intention?", International Journal of Business and Information, (2016).

[18] Kuncoro M, "Metode kualititatif: teori dan aplikasi untuk bisnis dan ekonomi”, Yogyakarta: Sekolah Tinggi Ilmu YKPN, (2013).

[19] Henseler J, Ringle CM \& Sarstedt M, "Testing measurement invariance of composites using partial least squares", International Marketing Review, Forthcoming, (2016).

[20] Chin WW, "The partial least squares approach for structural equation modeling", (1998), pp: 295-336 in Macoulides, G. A., ed. Modern methods for business research. Mahwah, NJ: Lawrence Erlbaum Associates.

[21] Garson GD, "Partial Least Squares: Regression \& Structural Equation Models", Asheboro, NC 27205 USA: Statistical Publishing Associates, (2016).

[22] Kock N \& Lynn GS, "Lateral Collinearity and Misleading Results in VarianceBased SEM: An Illustration and Recommendations,' Journal of the Association for Information Systems, Vol. 13, No.7, (2012), pp: 546-580.

[23] Ahmet A, "Customer Satisfaction Factor in Digital Content Marketing: Isparta Province as an Example”, (2016). 